\title{
EFFECTS OF COPPER ON SEED GERMINATION AND SEEDLING GROWTH PERFORMANCE OF LENS CULINARIS MEDIK.
}

\author{
Muhammad Zafar IQBAL ${ }^{1}$, Umm-e-HABIBA ${ }^{1}$, Sundus NAYAB $^{1}$, \\ $\underline{\text { Muhammad SHAFIQ }}^{{ }^{*}}$ \\ ${ }^{1}$ University of Karachi, Department of Botany, Karachi - Pakistan \\ *Corresponding author. E-mail: shafiqeco@yahoo.com
}

\begin{abstract}
The discharge of heavy metals in the environment due to anthropogenic, industrial and automobile activities is a worldwide environmental pollution problem. Copper is widely used in different forms in fertilizer, fungicides. Industrial effluents and for the removal algal growth in ponds. In this study the toxic effects of copper $(\mathrm{Cu})$ on seed germination and seedling growth of Lens culinaris were investigated. Germination rate of $L$. culinaris that showed that increased in concentration of copper treatment at $25 \mathrm{ppm}$ significantly $(\mathrm{p}<0.05)$ reduced germination percentage as compared to control. Seedling growth variables i.e. root and shoot length, seedling size and root/shoot ratio also declined significantly $(\mathrm{p}<0.05)$ with the treatment of copper at $25 \mathrm{ppm}$ as compared to control. Seedlings dry weight of L. culinaris gradually reduced with increased in all treatment of copper concentration as compared to control.

Tolerance indices and seedling vigor index of L. culinaris also decreased with increase in concentration of copper treatment. Low percentage of reduction in tolerance indices and seedling vigor index of $L$. culinaris was recorded at $25 \mathrm{ppm}$ copper treatment as compared to control. A high percentage of reduction in seedling tolerance indices of $L$. culinaris was recorded at $100 \mathrm{ppm}$ of copper treatment as compared to control.
\end{abstract}

Keywords: heavy metals, phytoxicity, seed germination, seedling growth, tolerance index.

\section{Introduction}

The group of elements have a density greater than $5 \mathrm{~g} / \mathrm{cm}^{3}$ belongs to heavy metals group [AGORAMOORTHY \& al. 2008]. The ever increase of heavy metal contamination in the environment has caused a serious environmental concern among researchers community. The effects of heavy metals on plant growth varied from species to species and the level of heavy metals available in the environment which may be beneficial or toxic to the plant growth environment. The essentials element likewise $\mathrm{Fe}, \mathrm{Zn}, \mathrm{Cu}$ or Mo are required in small quantities but at higher concentrations they may be poisonous for plant growth. Heavy metal contamination of soil and water causing toxicity/stress has become one important constraint to crop productivity and quality [SINGH \& al. 2016]. Among the heavy metals copper can be considered important heavy metals for ecotoxicology concern. The effects of copper upon seedling growth of Cucumis sativus, carrot, maize and wild plant species on bioaccumulation, yield of tomato and mineral nutrients were reported [MOUSTAKAS \& al. 1997; STOYANOVA \& DONCHEVA, 2002; ROUT \& DAS, 2003; AN \& al. 2004; SONMEZ \& al. 2006; MAHMOOD \& al. 2005; AN, 2006; XU \& al. 2006; AUDA \& ALI, 2010; MUHAMMAD \& al. 2011]. Copper is an essential micronutrient and is easily absorbed by plants. Its optimal content in plants tissues is reported to be $5-20 \mu \mathrm{g} \mathrm{g}^{-1}$ [FERNANDEZ \& HERNIQUES, 1991]. High concentrations of $\mathrm{Cu}$ become extremely toxic 
for root growth inhibition [FARGASAVA 2001]. Rice grain yields decreased exponentially and significantly with the increase of soil Cu levels. Rice grain yield was reduced about $10 \%$ by soil $\mathrm{Cu}$ level of $100 \mathrm{mg} \mathrm{kg}(-1)$, about $50 \%$ by soil $\mathrm{Cu}$ level of $300-500 \mathrm{mg} \mathrm{kg}(-1)$ and about $90 \%$ by soil $\mathrm{Cu}$ concentration of $1,000 \mathrm{mg} \mathrm{kg}(-1)$. Copper treatment at $0.5 \mathrm{mM}$ inhibited the root growth of two lentil cultivars viz. cv. Krak and cv. Tina [JENAS \& al. 2015].

Copper is toxic heavy metals and high concentration can be harmful for agriculture cops. The excess concentration of copper induced huge losses in agricultural crops viz wheat, iron, maize, sunflowers and cucumber production [ADREES \& al. 2015]. Lentil is an edible pulse, oldest crop [SULTANA \& GHAFOOR, 2006] and predominantly successfully cultivated in South East Asia and Turkey, Syria, Egypt, Iran and Pakistan. L. culinaris is annual leguminous popular crop due to its lens shaped seed and is a main source of vegetable protein. L. culinaris is a rabi legume plant and cultivated on large area in Pakistan [RAHMAN $\&$ al. 2013]. Little is known about the effects of copper on growth of an important crop lentil. Therefore, the aim of the present study was to evaluate the effects of copper on seed germination and seedling growth performance of L. culinaris.

Lentils (Lens culinaris Medik.) is an important legume pulse crop in world for millions of people as source of food. SZILAGY \& al. (2011) examined the stability for seed yield in lentils (Lens culinaris Medik) in Romania. At present in Romania, lentils grown on the lower areas, the only lentil Romanian cultivar being 'Oana'. The temperature hydration kinetics of Lens culinaris was evaluated in water at different temperature [OROIAN, 2017].

\section{Materials and methods}

The healthy seeds of Lens culinaris Medik were collected from the local market. The seeds were surface sterilized with $0.2 \%$ dilute solution of Sodium-hypo chlorite for two minutes to prevent any fungal contamination. The seeds were washed with double distilled water. Ten seeds were placed in Petri dishes (90 mm diameter) uniformly on filter paper added at proper place and covered with lid to prevent loss of mixture through evaporation. Solutions of copper sulfate were prepared having five concentrations $(0,25,50,75$ and 100 $\mathrm{ppm}$ ) concentrations. At the start of the experiment, $3 \mathrm{ml}$ of solution of above treatment were applied to each set of respective treatment. After two days the old solution from every petri plate was sucked out and $2 \mathrm{ml}$ fresh solution of respective treatment was added. The distilled water was added to each set of control treatment. The control received only $1 \mathrm{ml}$ of distilled water on alternate days. The experiments were designed on the basis of three replicates and the Petri dishes were kept at room temperature $\left(32 \pm 2{ }^{\circ} \mathrm{C}\right)$ with 240 Lux light intensity and the experiment lasted for ten days. The experiment was completely randomized. Seed germination, root, shoot, seedling lengths, seedling dry weight and root / shoot ratio was recorded. Three seedlings having maximum from each petri plate was sampled to measure the seedling growth variable. The dry biomass was determined by placing the seedling in an oven at $80{ }^{\circ} \mathrm{C}$ for 24 hours. Seedling vigor index (S.V.I) was determined as per the formula given by BEWLY \& BLACK (1982). Tolerance indices of seedlings were determined with the help of the following formula.

$$
\text { Tolerance indices }(\text { T.I. })=\frac{\text { Mean root length of treated seedlings }}{\text { Mean root length of control seedlings }} \times 100
$$


The seed germination and seedling growth data were statistically analyzed by Analysis of Variance (ANOVA) and Duncan's Multiple Range Test (DMRT) to determine the level of significance at $p<0.05$ on personnel computer using COSTAT version 3 .

\section{Results}

The different concentrations of heavy metal treatment as copper sulfate on Lens culinaris indicated low percentage of seed germination, seedling growth, seedling dry weight and root/shoot ratio as compared to control. The results indicated that root is strongly affected as compared to shoot by copper treatment. An increased in concentration of $\mathrm{Cu}$ produced more toxic effects on seedling dry weight and root / shoot ratio of L. culinaris as compared to control treatments (Figure 1-2; Table 1).

Copper treatment at $25 \mathrm{ppm}$ not significantly affected seed germination percentage of L. culinaris as compared to control (Table 1). The percentage of seed germination was significantly $(\mathrm{p}<0.05)$ reduced to $76.66,66.66$ and $56.66 \%$ at 50,75 and $100 \mathrm{Cu}$ treatment as compared to control (100\%). Copper treatment showed that root growth of L. culinaris was decreased with increase in concentration up to $100 \mathrm{ppm}$. The treatment of $\mathrm{Cu}$ showed more adverse effects on shoot growth of L. culinaris as compared to control. Results showed that shoot growth parameters were also declined with increase in concentration from 25 to 100 ppm of $\mathrm{Cu}$. The treatments of $\mathrm{Cu}$ at $25 \mathrm{ppm}$ increased shoot length $12.72 \mathrm{~cm}$ of L. culinaris over control $8.87 \mathrm{~cm}$ and significantly decreased to 7.0, 5.87, and 5.07 with the treatment at 50,75 and $100 \mathrm{ppm}$, respectively. Seedling size which consists on the length of root and shoot was recorded as $16.77 \mathrm{~cm}$ for control which decreased to $13.97 \mathrm{~cm}, 7.96 \mathrm{~cm}, 5.43 \mathrm{~cm}$ and $5.49 \mathrm{~cm}$ when treated with 25, 50, 75 and $100 \mathrm{ppm}$ copper solution treatment. Copper treatment at all concentration influenced the seedling dry weight of $L$. culinaris. Seedling dry weights of L. culinaris when treated with different concentration of $\mathrm{Cu}$ was reduced to 0.03 $\mathrm{g}$ to $0.0133 \mathrm{~g}$ at 25 and $100 \mathrm{ppm}$ concentration as compared to control. Results indicated that reduction was observed in root/shoot ratio with the increase in concentration copper particularly at 75 and $100 \mathrm{ppm}$.

\begin{tabular}{|c|c|c|c|c|c|c|}
\hline 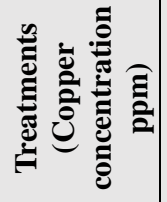 & $\begin{array}{c}\text { Germination } \\
(\%)\end{array}$ & $\begin{array}{l}\text { Root } \\
\text { length } \\
(\mathrm{cm})\end{array}$ & $\begin{array}{l}\text { Shoot } \\
\text { length } \\
(\mathrm{cm})\end{array}$ & $\begin{array}{l}\text { Seedling } \\
\text { size }(\mathrm{cm})\end{array}$ & $\begin{array}{l}\text { Seedling } \\
\text { dry } \\
\text { veight (g) }\end{array}$ & $\begin{array}{c}\text { Root/shoot } \\
\text { Ratio }\end{array}$ \\
\hline 00 & $100.00 \pm 3.33 \mathrm{a}$ & $9.46 \pm 0.06 \mathrm{a}$ & $8.87 \pm 0.06 \mathrm{a}$ & $16.77 \pm 0.06 \mathrm{a}$ & $0.034 \pm 0.98 \mathrm{a}$ & $1.72 \pm 0.01 \mathrm{a}$ \\
\hline 25 & $100.00 \pm 5.77 \mathrm{a}$ & $1.19 \pm 0.12 b$ & $12.72 \pm 0.9 \mathrm{~b}$ & $13.93 \pm 0.20 b$ & $0.030 \pm 2.64 b$ & $0.091 \pm 0.01 b$ \\
\hline 50 & $76.66 \pm 3.33 b$ & $0.95 \pm 0.18 b$ & $7.00 \pm 0.2 b c$ & $7.96 \pm 0.4 \mathrm{c}$ & $0.020 \pm 3.38 b$ & $0.133 \pm 0.02 b$ \\
\hline 75 & $61.66 \pm 0.00 \mathrm{c}$ & $0.28 \pm 0.14 b$ & $5.87 \pm 0.18 \mathrm{c}$ & $5.43 \pm 0.33 \mathrm{~d}$ & $0.0133 \pm 2.96 b$ & $0.033 \pm 0.00 \mathrm{~b}$ \\
\hline 100 & $51.66 \pm 3.33 \mathrm{~d}$ & $0.40 \pm 0.03 b$ & $5.07 \pm 0.25 \mathrm{c}$ & $5.49 \pm 0.27 \mathrm{~d}$ & $0.0133 \pm 2.88 b$ & $0.091 \pm 0.006 \mathrm{~b}$ \\
\hline L.S.D. & 8.13 & 2.25 & 1.09 & 2.28 & 0.01 & 0.12 \\
\hline
\end{tabular}


The seedlings of L. culinaris showed lowest percentage of tolerance indices were recorded for $100 \mathrm{ppm}$ of $\mathrm{Cu}$ treatment as compared to control (Figure 1). Similarly, Seedling Vigor Index (S.V.I.) for L. culinaris seedling was recorded highest in control and gradually declined with the increase in concentration of $\mathrm{Cu}$ treatments from 25 to $100 \mathrm{ppm}$ (Figure 2).

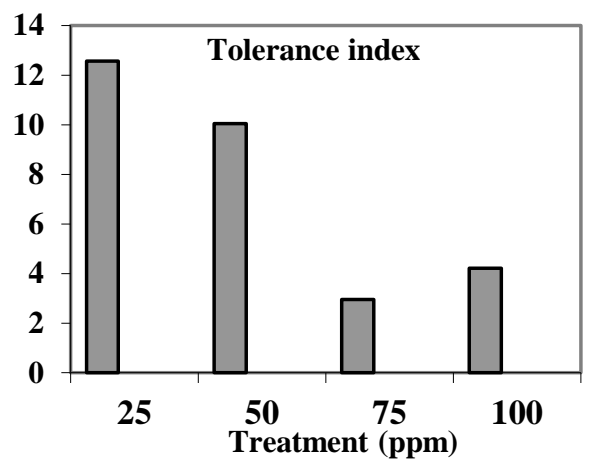

Figure 1. Percentage of tolerance in L. culinaris using different concentration $(0,25,50,75,100 \mathrm{ppm})$ of copper $(\mathrm{Cu})$

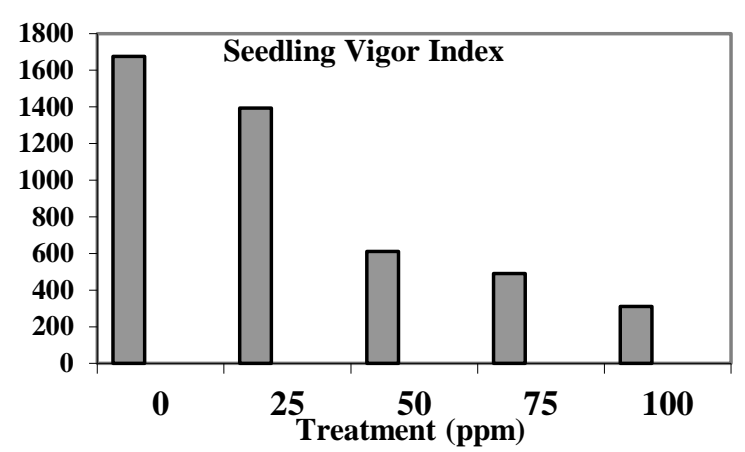

Figure 2. Seedling vigor index for L. culinaris using different concentration $(0,25,50,75,100 \mathrm{ppm})$ of copper

\section{Discussion}

Excessive concentration of copper generally produce common toxic effects on different growth variable of plants, such as low biomass accumulation, chlorosis, inhibition of growth and photosynthesis, altered water balance and nutrient assimilation, and senescence, which ultimately cause plant death. The plant under abiotic stress conditions are most likely to be adversely affected by heavy metals contamination. In present studies the toxicity and tolerance of copper on seed germination and seedling growth performances of L. culinaris were found significantly affected at higher concentration of copper treatment. Copper treatment at $25 \mathrm{ppm}$ did not produce any significant effect on seed germination which 
MUHAMMAD ZAFAR IQBAL \& al.

might be due to its resistance to copper. The effect of the $\mathrm{Cu}$ at $25 \mathrm{ppm}$ concentration on root growth of L. culinaris was observed and agreed with the findings of ISMAIL \& al. (2013). Exposure to $25 \mathrm{ppm}$ concentration of $\mathrm{Cu}$ reduced the root length of $L$. culinaris as compared with the root length of control. In another studies, the copper treatment in resin buffered solution culture at $<1 \mu \mathrm{M}$ produced toxic effects on the root morphology of a pasture species, Rhodes grass (Chloris qayana Knuth.) observed [SHELDON \& MENZIES, 2005]. Similarly, the increasing concentrations of $\mathrm{Cu}$ significantly inhibited the growth of young sweet potato plants (Ipomoea batatas) reported earlier [KIM \& al. 2010].

Results also showed that seedling dry weights of $L$. culinaris were also declined with increased concentration of copper sulphate and this reduction was more prominent with increasing concentration of copper in substrate. The increase in concentration of copper upto $100 \mathrm{ppm}$ was found responsible for decreased the seedling growth of L. culinaris as compared to control treatment. Copper treatment at all concentration none significantly affected seedling dry weight as compared to control. The results indicated that increasing concentrations of $\mathrm{Cu}$ in seedlings tissues significantly $(\mathrm{p}<0.05)$ reduced the seedlings growth. In addition to growth inhibition of L. culinaris copper treatment reduced root / shoot ratio.

The effects of $\mathrm{Cu}$ on the plant growth have been reported in some studies over the past few years. At the cellular level, oxidative stress has been reported as a common mechanism in both stress situations [SMEETS \& al. 2009]. The treatment of copper produced toxic effects on germination and growth of L. culinaris. Lowest percentage of tolerance indices for L. culinaris seedlings were recorded for 100 ppm copper treatment.

\section{Conclusion}

It was concluded that the copper treatment produced toxic effects on seed germination and seedling growth of $L$. culinaris along with significant reduction in seedling dry weight as compared to control treatment. Similarly, the tolerance to copper treatment decreased the tolerance indices for $L$. culinaris seedlings with the increase in metal concentration in the substrate as compared to control. The difference in tolerance and seedling vigor index in response to copper toxicity should be considered while L. culinaris cultivated in copper contaminated areas. There is a need to be carried out further studies on other copper tolerant species for plantation in copper contaminated areas to overcome the shortage of agriculture crops.

\section{Notes on contributors}

Muhammad Zafar IQBAL - Ph.D., Professor, designed and supervised the experiment. Umme-HABIBA - M.Sc., Research scientist, performed the experiment. Sundus NAYAB - M.Sc., Research scientist, performed the experiment and assisted to collect the data. Muhammad SHAFIQ - Ph.D., Research scholar statistically analysed the experimental data, reviewed the literature and draft the manuscript.

\section{References}

ADREES M., ALI S., RIZWAN M., IBRAHIM M., ABBAS F., FARID M., ZIA-UR-REHMAN M., IRSHAD M. K. \& BHARAWANA S. A. 2015. The effect of excess copper on the growth and physiology of important food crops; a review. Enviorn. Sci. Pollut. Res. Int. 22(11): 8148-8162.

AGORAMOORTHY G. F, CHEN \& HSU M. J. 2008. Threat of heavy metal pollution in halophytic and mangrove plants of Tamil Nadu, India. Environmental Pollution. 155(2): 320-326.

AN J. 2006. Assessment of comparative toxicities of lead and copper using plant assay. Chemo. 62(8): 1359-1365. 
AN Y., KIM Y., KWON T. \& JEONG S. 2004. Combined effect of copper, cadmium, and lead upon Cucumis sativus growth and bioaccumulation. Science of the Total Environment. 326: 85-93.

AUDA A. M. \& ALI E. S. 2010. Cadmium and zinc toxicity effects on growth and mineral nutrients of carrot (Daucus carota). Pakistan Journal of Botany. 42: 341-351.

BEWLY J. D. \& BLACK B. M. 1982. Germination of seeds. In: Physiology and biochemistry of seed germination. NewYork: Edit. A. A. Khan, Springer Verlag, pp. 40-80.

FARGASOVA A. 2001.Toxic effects of $\mathrm{Cd}, \mathrm{Zn}, \mathrm{Pb}, \mathrm{Cu}$ and $\mathrm{Fe}$ on the Sinapis alba $\mathrm{L}$. seedlings and their accumulation in roots and shoots. Biologia Plantarum. 44: 471-173.

FERNANDEZ J. C. \& HENRIQUES F. S. 1991. Biochemical, physiological and structural effects of excess copper in plants. Botanical Rev. 57: 246-273.

ISMAIL S., KHAN F. \& IQBAL M. Z. 2013. Phytoremediation: Assessing tolerance of tree species against heavy metals $(\mathrm{Pb}$ and $\mathrm{Cd})$ toxicity. Pak. J. Bot. 45(6): 2181-2186.

JANAS K. M., ZIELIŃSKA-TOMASZEWSKAJ., RYBACZEK D., MASZEWSKI J., POSMYK M. M., AMAROWICZ R. \& KOSINSSKA A. 2010. The impact of copper ions on growth, lipid peroxidation, and phenolic compound accumulation and localization in lentil (Lens culinaris Medic.) seedlings. J. Plant Physiol. 167(4): 270-276.

KIM Y., LEE H. S. \& KWAK S. S. 2010. Differential responses of sweetpotato peroxidases to heavy metals. Chemosphere. 81(1): 79-85.

MAHMOOD S., HUSSAIN A., SAEED Z. \& ATHAR M. 2005. Germination and seedling growth of corn (Zea mays L.) under varying levels of copper and zinc. International Journal of Environmental Science and Technology. 2: 269-274.

MOUSTAKAS M., OUZOUNIDOU G. \& SYMCONIDIS L. 1997. Field study of the effects of excess copper on wheat photosynthesis and productivity. Soil Sci. and Plant Nut. 43: 531-539.

MUHAMMAD S., SHAH M. T. \& KHAN S. 2011. Heavy metal concentrations in soil and wild plants growing around $\mathrm{Pb}-\mathrm{Zn}$ sulfide terrain in the Kohistan region, northern Pakistan. Microchemical Journal. 99: 67-75.

OROIAN M. 2017. The temperature hydration kinetics of Lens culinaris. Journal of the Saudi Society of Agricultural Sciences. 16(3): 250-256.

RAHMAN M. H., WAJID S. A., AFZAL M., AWAIS M., IRFAN M. \& AHMAD A. U. H. 2013. Performance of promising lentil (Lens culinaris Medik.) cultivars at different nitrogen rates under irrigated conditions of Faisalabad, Pakistan. Cercetari Agronomice in Moldova. 46(3): 79-87. https://doi.org/10.2478/v10298-0120095-5

ROUT G. R. \& DAS P. 2003. Effect of metal toxicity on plant growth and metabolism: I. Zinc. Agronomy. 23: 311.

SHELDON A. R. \& MENZIES N. W. 2005. The effect of copper toxicity on the growth and root morphology of Rhodes grass (Chloris qayana Knuth.) in resin buffered solution culture. Plant and Soil. 278(1-2): 341-349.

SINGH S., PARIHAR P., SINGH R., SINGH V. P. \& PRASAD S. M. 2016. Heavy metal tolerance in plants: Role of transcriptomics, proteomics, metabolomics, and ionomics. Front. Plant Sci. 6: 1143.

SMEETS K., OPDENAKKER K., REMANS T., SANDEN S. V., BELLEGHEM F. V., SEMANE B., HOREMAN B., GUISEZ Y., VANGRONSVELD J. \& CUYPERS A. 2009. Oxidative stress-related responses at transcriptional and enzymatic levels after exposure to $\mathrm{Cd}$ or $\mathrm{Cu}$ in a multipollution context. $J$ of Plant Physio. 166(18): 1982-1992.

SONMEZ S., KAPLAN M., SONMEZ N. K., KAYA H. \& URZ I. 2006. High level of copper application to soil and leaves reduce the growth and yield of tomato plants. Sci. Agric. (Piracicaba, Braz.). 63(3): 213-218.

STOYANOVAZ. \& DONCHEVA S. 2002. The effect of zinc supply and succinate treatment on plant growth and mineral uptake in pea plant. Braz. Journal of Plant Physiology. 14: 111-116.

SULTANA T. \& GHAFOOR A. 2006. Genetic diversity in ex-situ conserved Lens culinaris for botanical descriptors, biochemical and molecular markers and identification of landraces from indigenous genetic resources of Pakistan. J. Integr Plant Biol. 50(4): 484-490.

SZILAGY L., AL-ABBOUD I. \& ROMAN GHV. 2011. Stability analysis for seed yield lentils (Lens culinaris Medik.). Scientific Papers, UASVM Bucharest, Series A. 54: 338-343.

XU J., YANG L., WANG Z., DONG G., HUANG J. \& WANG Y. 2006. Toxicity of copper on rice growth and accumulation of copper in rice grain in copper contaminated soil. Chemosphere. 62: 602-607.

\section{How to cite this article:}

IQBAL M. Z., HABIBA U., NAYAB S. \& SHAFIQ M. 2018. Effects of copper on seed germination and seedling growth performance of Lens culinaris Medik. J. Plant Develop. 25: 85-90. https://doi.org/10.33628/jpd.2018.25.1.85 